\title{
Serum interleukin-35 and pentraxin-3 levels in patients with mild acute pancreatitis
}

\author{
Evrim Kahramanoğlu Aksoy², Ferdane Pirinççi Sapmaz', Özlem Doğan², Zeynep Göktaş3, Metin Uzman ${ }^{1}$, \\ Yaşar Nazlıgül ${ }^{1}$ \\ 1Department of Gastroenterology, Kecioren Training and Research Hospital, Ankara, Turkey \\ ${ }^{2}$ Department of Biochemistry, Faculty of Medicine, Ankara University, Ankara, Turkey \\ ${ }^{3}$ Department of Nutrition and Dietetics, Faculty of Health Sciences, Hacettepe University, Hacettepe, Turkey
}

Gastroenterology Rev 2019; 14 (1): 48-54

DOI: https://doi.org/10.5114/pg.2019.83425

Key words: mild acute pancreatitis, interleukin-35, pentraxin-3.

Address for correspondence: Evrim Kahramanoğlu Aksoy MD, Department of Gastroenterology, Kecioren Training and Research Hospital, 06380 Ankara, Turkey, phone: +90 3123169000, e-mail: evrims1979@yahoo.com

\begin{abstract}
Introduction: Interleukin-35 (IL-35) is a newly defined potent anti-inflammatory cytokine that is predominantly produced by regulatory $T$ cells, and pentraxin- 3 belongs to the acute-phase proteins.

Aim: To measure the serum IL-35 and pentraxin-3 levels in the early phase of mild acute pancreatitis (AP).

Material and methods: Eighty-three patients with mild AP and 30 healthy controls were included in the study. The serum levels of IL-35 and pentraxin-3 were measured by enzyme-linked immunosorbent assay upon admission and at the $48^{\text {th }}$ hour after diagnosis.

Results: The mean value of serum IL-35 levels in patients with mild acute pancreatitis at admission was $5.91 \mathrm{ng} / \mathrm{ml}(4.21-$ $7.90)$ and was significantly lower than those in healthy controls $(25.53 \mathrm{ng} / \mathrm{ml}(12.79-54.73, p<0.001))$ and 48-hour value were $(6.79 \mathrm{ng} / \mathrm{ml}(4.42-9.62)(p=0.015))$. The mean value of serum pentraxin-3 levels in patients at the time of admission was $6.75 \mathrm{ng} / \mathrm{ml}$ (4.42-9.62) and there was no significant difference from healthy controls, at $7.64 \mathrm{ng} / \mathrm{ml}(6.58-8.62, p>0.05)$. Also there was no significant difference between the mean value at admission and the mean value at 48 -hour, $6.75 \mathrm{ng} / \mathrm{ml}(4.74-9.06, p>0.05)$.

Conclusions: Interleukin-35 can be used in diagnosis and follow-up in patients with mild AP.
\end{abstract}

\section{Introduction}

Acute pancreatitis (AP) is an acute inflammatory disease of the pancreas and is characterised by sudden onset of upper abdominal pain and elevation of serum pancreatic enzymes [1]. The most common causes are excessive alcohol consumption and gallstones. Other rare causes are post endoscopic-retrograde cholangiopancreatography (ERCP), drugs, viral infections, hypertriglyceridemia, hypercalcemia, abdominal trauma, and other idiopathic reasons [2]. About $80 \%$ of all AP cases have a mild course and resolve without any complications, only with supportive care. But $20 \%$ of all cases develop severe acute pancreatitis, and it is associated with persistent organ failure and a mortality rate of $5-70 \%$. Early diagnosis and accurate prognostic evaluation play an important role in reducing mortality and morbidity [3].

It has been widely accepted that trypsin activation within pancreatic acinar cells is the initiating condition that leads to pancreas autodigestion. As trypsin is activated the attraction and activation of polymorphonuclear leukocytes, macrophages, and lymphocytes starts. They release proinflammatory mediators such as interleukin-1 (IL-1), IL-6, IL-18, tumour necrosis factor $\alpha$ (TNF- $\alpha$ ), oxygen free radicals, adhesion molecules, chemokines, and anti-inflammatory cytokines such as IL-11 and IL-10. These substances stimulate the inflammatory process in the gland. If inflammation is not sufficiently restricted by anti-inflammatory cytokines, localised inflammation enhances to systemic inflammation and may lead to tissue damage, organ failure, and death [4, 5].

Little is known about the effects of anti-inflammatory cytokines in AP although much more is known about proinflammatory cytokines. Interleukin-10 is one of the most studied anti-inflammatory cytokines studied in AP [6-8]. But there is a discrepancy among studies in terms of serum IL-10 levels. While in some studies serum IL-10 
levels were significantly higher in mild AP than severe $A P$, it was found to be low in others $[6,7]$. In one study it was revealed that serum IL-10 and IL-11 levels signifies the severity of AP. IL-10 and IL-11 have been shown to decrease the severity of AP [6].

Interleukin-35 is a heterodimeric cytokine, which is composed of the Epstein-Barr virus-induced gene 3 (EBI3) and the p35 subunit of IL-12. It is a newly defined potent anti-inflammatory cytokine that is predominantly produced by Foxp3+ regulatory $T$ cells (Tregs). It supresses T-helper (Th) 1, Th2, and Th17 cell responses and plays an important role in host immunity [9]. Interleukin-35 expression is affected in some immune and inflammatory conditions such as systemic sclerosis, asthma and chronic obstructive pulmonary disease (COPD), rheumatoid arthritis, inflammatory bowel disease, and sepsis [9-13].

Acute-phase proteins: TNF- $\alpha$, IL-6, serum amyloid A (SAA), and more commonly $C$ - reactive protein (CRP) are used in the evaluation of AP patients [14, 15]. Pentraxin-3 is a member of the pentraxin family, and it is a secretory protein classified as a long pentraxin. Both CRP and SAA belong to the short pentraxin subfamily. Pentraxin-3 is expressed by a variety of cells at inflammatory sites and released from neutrophil-specific granules when stimulated with proinflammatory cytokines, bacterial lipopolysaccharides, or by the activation of Toll-like receptors (TLR). Elevated serum pentraxin-3 levels were found in several diseases such as cardiovascular diseases, malignancies, specific infections, and sepsis and correlated with organ dysfunction [16].

\section{Aim}

The aim of this study was to evaluate serum pentraxin-3 and IL-35 levels in the early phase of mild AP.

\section{Material and methods \\ Patients}

The study included 83 patients admitted to the Kecioren Training and Research Hospital, Ankara, Turkey between March 2017 and June 2017 with AP symptoms within 36 hours before admission. The diagnosis of AP was based on acute abdominal pain, three-fold increase in pancreatic enzymes (amylase and/or lipase), and abdominal ultrasound. The severity of disease was classified according to the revised Atlanta classification system, and all patients had mild disease. None of the patients had a history of AP and all of them hospitalised for palliative treatment. The time duration between pain onset and hospital admission was as follows: 0-6 $\mathrm{h}$ in 12 patients, $6-12 \mathrm{~h}$ in 26 patients, $12-24 \mathrm{~h}$ in 31 patients, and $24-36 \mathrm{~h}$ in 14 patients. Forty-three pa- tients had biliary originated pancreatitis, 2 patients had alcohol-induced pancreatitis, 2 patients had hypertriglyceridemia-related pancreatitis, and 36 patients had idiopathic pancreatitis. There were no AP patients due to drug, metabolic causes and anatomical abnormalities. On evaluation, 24 patients had pancreatic oedema, 2 patients had peripancreatic fluid, 9 patients had pancreatic oedema and peripancreatic fluid, and 2 patients had pancreatic or peripancreatic necrosis (Table I).

The implementation of the study was endorsed by an Ethics Committee (26.04.2017, 2012-kaek-15/1407).

\section{Measurement of serum IL-35 and pentraxin-3 levels}

Serum samples were collected at the time of diagnosis and at the $48^{\text {th }} \mathrm{h}$ after diagnosis. Within 30 min following collection, the blood was centrifuged (5000 rpm, $5 \mathrm{~min}$ ) and the serum samples stored at $-80^{\circ} \mathrm{C}$ until analysis. Serum IL-35 concentrations were quantified by using a commercial human IL-35 ELISA kit (Eastbiopharm, China) and human pentraxin-3 ELISA kit (Boster Immunoleader, USA), according to the manufacturers' protocols. All samples were assayed in duplicate. The mean concentration was determined for each sample.

Table I. Clinical characteristics of acute pancreatitis patients $(n=83)$

\begin{tabular}{lc} 
Clinical characteristics & $\boldsymbol{N}(\%)$ \\
\hline Aetiology of AP: & $43(51.8)$ \\
\hline Biliary & $2(2.4)$ \\
\hline Alcohol & $2(2.4)$ \\
\hline Hypertriglyceridaemia & $36(43.4)$ \\
\hline Idiopathic & $12(14.5)$ \\
\hline Onset of pain: & $26(31.3)$ \\
\hline 0-6 h ago & $31(37.3)$ \\
\hline 6-12 h ago & $14(16.9)$ \\
\hline 12-24 h ago & $24(28.9)$ \\
\hline 24-36 h ago & $2(2.4)$ \\
\hline Ultrasonographic findings: & $9(10.8)$ \\
\hline Pancreatic oedema & $2(2.4)$ \\
\hline Peripancreatic fluid & $46(55.5)$ \\
\hline Pancreatic oedema and peripancreatic fluid & $83(100.0)$ \\
\hline Pancreatic or peripancreatic necrosis & \\
\hline Normal findings &
\end{tabular}




\section{Statistical analysis}

Statistical analyses were performed using the computer program SPSS 22.0 (IBM, USA). Levene's test of normality was used to test the distribution of variables. Independent sample $t$-test and paired sample $t$-test were used for comparison of more than two group means. Mann Whitney- $U$ and Kruskal Wallis tests were used to analyse nonparametric data. The $\chi^{2}$ test was used to compare nominal data between AP and control groups. Pearson correlation was used to evaluate the linear relationship between the tested biomarkers. Data were presented as means \pm standard deviation or number and percentage. Differences were considered significant at $p<0.05$.

\section{Results}

\section{Serum IL-35 and penraxin-3 levels in patients with acute pancreatitis}

A total of 83 patients with AP and 30 healthy controls were evaluated for serum levels of IL-35 and pentraxin-3. The demographic features of the patients included in the study are summarised in Table II. There were no significant differences between the AP and control group with respect to age, gender, smoking status, hypertension, and body mass index (BMI) $(p>0.05)$. As shown in Table III, the mean value of the serum IL-35 level in patients with acute pancreatitis at admission was $5.91 \mathrm{ng} / \mathrm{ml}$ (4.21-7.90), which was significantly lower than in healthy controls $-25.53 \mathrm{ng} / \mathrm{ml}$ (12.79-54.73, $p<0.001)$. The mean value of serum IL-35 at the $48^{\text {th }} \mathrm{h}$ was $6.79 \mathrm{ng} / \mathrm{ml}$ (4.42-9.62) and there was a significant difference between that and the admission value $(p=0.015)$. There was also a significant difference between the serum IL-35 levels at the $48^{\text {th }} \mathrm{h}$ in patients with AP and in healthy controls $(p<0.001)$. The mean value of serum pentraxin-3 levels in patients at the time of admission was $6.75 \mathrm{ng} / \mathrm{ml}$ (4.42-9.62) and there was no significant difference between that and healthy controls, $7.64 \mathrm{ng} / \mathrm{ml}(6.58-8.62, p>0.05)$. There was no significant difference between the mean value at admission and the mean value at the $48^{\text {th }} \mathrm{h}$, $6.75 \mathrm{ng} / \mathrm{ml}(4.74-9.06, p>0.05)$ (Figure 1).

\section{The relationship between aetiology and serum IL-35 and pentraxin-3 levels}

As shown in Table IV, the median and interquartile range values of serum IL-35 levels in patients with AP due to biliary and idiopathic aetiology were 6.30 (4.66$8.11) \mathrm{ng} / \mathrm{ml}$ and $5.60(3.63-6.81) \mathrm{ng} / \mathrm{ml}$ on admission and $6.87(5.10-9.53) \mathrm{ng} / \mathrm{ml}$ and $5.98(4.13-9.32) \mathrm{ng} / \mathrm{ml}$ at the $48^{\text {th }} \mathrm{h}$, respectively. There was no significant difference between these groups. Alcohol and hypertriglyceridaemia aetiology groups were disregarded due to low sample size (2 patients in each group). The median and interquartile range values of serum pentraxin-3 levels in patients with AP due to biliary and idiopathic aetiology were $6.34(4.26-8.92) \mathrm{ng} / \mathrm{ml}$ and 7.16 (4.54-10.97) ng/ $\mathrm{ml}$ on admission and $6.85(4.70-8.86) \mathrm{ng} / \mathrm{ml}$ and 6.41 (4.85-9.91) $\mathrm{ng} / \mathrm{ml}$ at the $48^{\text {th }} \mathrm{h}$, respectively. There was no significant difference between these groups.

\section{Results of selected laboratory tests and correlations between serum IL-35 and serum pentraxin- 3 levels}

There were significant differences in serum amylase (592 U/I (292-1200) and $80 \mathrm{U} / \mathrm{l}(61-123), p<0.001)$, lipase (1200 U/l (623-1994) and $67 \mathrm{U} / \mathrm{l}(36-173)$, $p<0.001)$, C-reactive protein $(2.02 \mathrm{mg} / \mathrm{ml}(0.70-5.46)$ and $2.18 \mathrm{mg} / \mathrm{ml}(0.61-7.93), p=0.008)$, leukocyte

Table II. Characteristics of subjects

\begin{tabular}{|c|c|c|c|}
\hline Characteristic & $\begin{array}{l}\text { Acute pancreatitis } \\
(n=83) \\
N(\%) \text { or mean } \pm \text { SD }\end{array}$ & $\begin{array}{l}\text { Control } \\
(n=30)\end{array}$ & $P$-value* \\
\hline Age [years] & $52.9 \pm 15.61$ & $47.1 \pm 13.95$ & NS \\
\hline Female sex & $53(63.9)$ & $18(60.0)$ & NS \\
\hline Smokers & $25(30.1)$ & $12(40.0)$ & NS \\
\hline BMI $\left[\mathrm{kg} / \mathrm{m}^{2}\right]$ & $26.5 \pm 3.53$ & $25.8 \pm 3.53$ & NS \\
\hline $\mathrm{HDL}[\mathrm{mg} / \mathrm{dl}]$ & $42.3 \pm 12.44$ & $58.7 \pm 12.39$ & $<0.001$ \\
\hline $\mathrm{LDL}[\mathrm{mg} / \mathrm{dl}]$ & $106.9 \pm 36.18$ & $86.4 \pm 18.55$ & 0.017 \\
\hline Total cholesterol [mg/dl] & $135.8 \pm 166.47$ & $109.5 \pm 26.44$ & NS \\
\hline Triglycerides [mg/dl] & $172.4 \pm 54.77$ & $158.6 \pm 33.05$ & NS \\
\hline
\end{tabular}

*t test and $\chi^{2}$ test were used for analysis. BMI - body mass index, HDL - high-density lipoprotein, $L D L$ - low-density lipoprotein. 
Table III. Results of selected laboratory tests at the time of diagnosis and at $48 \mathrm{~h}$ from the onset of AP

\begin{tabular}{|c|c|c|c|c|}
\hline Variable & Time point & $\mathrm{AP}(n=83)$ & Control $(n=30)$ & $P$-value ${ }^{*}$ \\
\hline Amylase $[\mathrm{U} / \mathrm{l}]$ & $\begin{array}{c}\text { Diagnosis } \\
48 \mathrm{~h}\end{array}$ & $\begin{array}{c}592(292-1200) \\
80(61-123)^{\star}\end{array}$ & $28.5(24.0-42.0)$ & $<0.001$ \\
\hline Lipase [U/I] & $\begin{array}{c}\text { Diagnosis } \\
48 \mathrm{~h}\end{array}$ & $\begin{array}{c}1200(623-1994) \\
67(36-173)^{\star}\end{array}$ & $24.8(22.0-32.0)$ & $<0.001$ \\
\hline C-reactive protein [mg/l] & $\begin{array}{c}\text { Diagnosis } \\
48 \mathrm{~h}\end{array}$ & $\begin{array}{l}2.02(0.70-5.46) \\
2.18(0.61-7.93)^{\star}\end{array}$ & $0.26(0.24-0.34)$ & NS \\
\hline Sedimentation rate $[\mathrm{mm} / \mathrm{h}]$ & $\begin{array}{c}\text { Diagnosis } \\
48 \mathrm{~h}\end{array}$ & $\begin{array}{c}14.5(6.0-24.3) \\
20.0(12.0-30.0)\end{array}$ & $12.0(10.0-14.0)$ & 0.012 \\
\hline Leukocytes $\left[\times 10^{3} / \mathrm{mm}^{3}\right]$ & $\begin{array}{c}\text { Diagnosis } \\
48 \mathrm{~h}\end{array}$ & $\begin{array}{c}9.3(7.1-11.4) \\
7.98(6.26-10.0)^{\star}\end{array}$ & $7.9(6.9-8.7)$ & 0.001 \\
\hline Neutrophils $\left[\times 10^{3} / \mathrm{mm}^{3}\right]$ & $\begin{array}{c}\text { Fiagnosis } \\
48 \mathrm{~h}\end{array}$ & $\begin{array}{c}7.13 \pm 3.73 \\
5.41 \pm 2.77^{\star} \\
\end{array}$ & $4.74 \pm 0.94$ & 0.005 \\
\hline Lymphocytes $\left[\times 10^{3} / \mathrm{mm}^{3}\right]$ & $\begin{array}{c}\text { Diagnosis } \\
48 \mathrm{~h}\end{array}$ & $\begin{array}{l}1.78 \pm 0.88 \\
2.13 \pm 1.39^{*}\end{array}$ & $2.65 \pm 0.83$ & $<0.001$ \\
\hline Monocytes $\left[\times 10^{3} / \mathrm{mm}^{3}\right]$ & $\begin{array}{c}\text { Diagnosis } \\
48 \mathrm{~h}\end{array}$ & $\begin{array}{l}0.65 \pm 0.24 \\
0.74 \pm 1.08\end{array}$ & $0.42 \pm 0.16$ & $<0.001$ \\
\hline RDW (\%) & $\begin{array}{c}\text { Diagnosis } \\
48 \mathrm{~h}\end{array}$ & $\begin{array}{l}15.5(14.8-16.4) \\
15.4(14.6-16.5)\end{array}$ & $15.6(15.5-16.0)$ & NS \\
\hline MPV $[\mathrm{fl}]$ & $\begin{array}{c}\text { Diagnosis } \\
48 \mathrm{~h}\end{array}$ & $\begin{array}{l}7.82(7.0-8.9) \\
7.76(7.0-9.2)\end{array}$ & $10.1(8.9-10.9)$ & NS \\
\hline PDW (\%) & $\begin{array}{c}\text { Diagnosis } \\
48 \mathrm{~h}\end{array}$ & $\begin{array}{l}18.0(17.2-19.0) \\
18.1(17.4-19.0)\end{array}$ & $16.8(16.6-17.2)$ & NS \\
\hline Platelet count $\left[\times 10^{3} \mu \mathrm{l}\right]$ & $\begin{array}{c}\text { Diagnosis } \\
48 \mathrm{~h}\end{array}$ & $\begin{array}{l}228.6 \pm 71.98 \\
233.2 \pm 79.36\end{array}$ & $269.2 \pm 38.39$ & 0.001 \\
\hline Haematocrit (\%) & $\begin{array}{c}\text { Diagnosis } \\
48 \mathrm{~h}\end{array}$ & $\begin{array}{l}37.9 \pm 5.24 \\
37.7 \pm 4.88\end{array}$ & $40.5 \pm 1.66$ & $<0.001$ \\
\hline Platelets $\left[\times 10^{3} / \mathrm{mm}^{3}\right]$ & $\begin{array}{c}\text { Diagnosis } \\
48 \mathrm{~h}\end{array}$ & $\begin{array}{c}0.18 \pm 0.06 \\
2.29 \pm 18.64 \\
\end{array}$ & $0.24 \pm 0.04$ & $<0.001$ \\
\hline Glucose $[\mathrm{g} / \mathrm{dl}]$ & $\begin{array}{c}\text { Diagnosis } \\
48 \mathrm{~h}\end{array}$ & $\begin{array}{c}99.0(88.0-122.0) \\
91.0(82.0-106.5)^{*}\end{array}$ & $93.0(86.0-98.0)$ & $<0.001$ \\
\hline Albumin $[\mathrm{g} / \mathrm{l}]$ & $\begin{array}{c}\text { Diagnosis } \\
48 \mathrm{~h}\end{array}$ & $\begin{array}{l}3.9(3.6-4.0) \\
3.9(3.3-4.0)\end{array}$ & $4.2(4.0-4.3)$ & $<0.001$ \\
\hline Urea [mg/dl] & $\begin{array}{c}\text { Diagnosis } \\
48 \mathrm{~h}\end{array}$ & $\begin{array}{c}26.7 \pm 11.98 \\
24.4 \pm 12.69^{\star}\end{array}$ & $28.1 \pm 6.92$ & NS \\
\hline Creatinine $[\mathrm{mg} / \mathrm{dl}]$ & $\begin{array}{c}\text { Diagnosis } \\
48 \mathrm{~h}\end{array}$ & $\begin{array}{l}0.84 \pm 0.47 \\
0.88 \pm 0.77\end{array}$ & $0.94 \pm 0.11$ & NS \\
\hline Calcium [mg/dl] & $\begin{array}{c}\text { Diagnosis } \\
48 \mathrm{~h}\end{array}$ & $\begin{array}{l}9.0(8.7-9.2) \\
9.0(9.0-9.2) \\
\end{array}$ & $10.1(9.7-10.2)$ & $<0.001$ \\
\hline $\mathrm{IL}-35[\mathrm{ng} / \mathrm{ml}]$ & $\begin{array}{c}\text { Diagnosis } \\
48 \mathrm{~h}\end{array}$ & $\begin{array}{c}5.91(4.21-7.90) \\
6.79(4.42-9.62)^{\star}\end{array}$ & $25.53(12.79-54.73)$ & $<0.001$ \\
\hline Pentraxin-3 [ng/ml] & $\begin{array}{c}\text { Diagnosis } \\
48 \mathrm{~h}\end{array}$ & $\begin{array}{l}6.75(4.42-9.62) \\
6.75(4.74-9.06)\end{array}$ & $7.64(6.58-8.62)$ & NS \\
\hline
\end{tabular}

*There is a significant difference between 24-h and 48-h levels ( $p<0.001, p<0.001, p=0.008, p=0.001, p<0.001, p=0.022, p=0.006, p=0.001$, and $p=0.015$, respectively). ${ }^{*}$-tests were used for analysis. RDW - red blood cell distribution width, MPW - mean platelet volume, PDW - platelet distribution width, IL-35 - interleukin-35.

count $\left(9.3 \times 10^{3}(7.1-11.4)\right.$ and $7.98 \times 10^{3}(6.26-10.0)$, $p=0.001)$, neutrophil count $\left(7.13 \pm 3.73 \times 10^{3}\right.$ and $\left.5.41 \pm 2.77 \times 10^{3}, p<0.001\right)$, lymphocyte count $(1.78$ $\pm 0.88 \times 10^{3}$ and $\left.2.13 \pm 1.39 \times 10^{3}, p=0.022\right)$, glucose (99.0 mmol// (88.0-122.0) and $91.0 \mathrm{mmol} / \mathrm{l}(82.0-$
106.5), $p=0.006)$, and urea (26.7 $\pm 11.98 \mathrm{mmol} / \mathrm{l}, 24.4$ $\pm 12.69 \mathrm{mmol} / \mathrm{l}, p=0.001$ ) levels on admission and at $48 \mathrm{~h}$, respectively.

There were positive correlations between amylase and IL-35 levels on admission and at the $48^{\text {th }} \mathrm{h}$ 

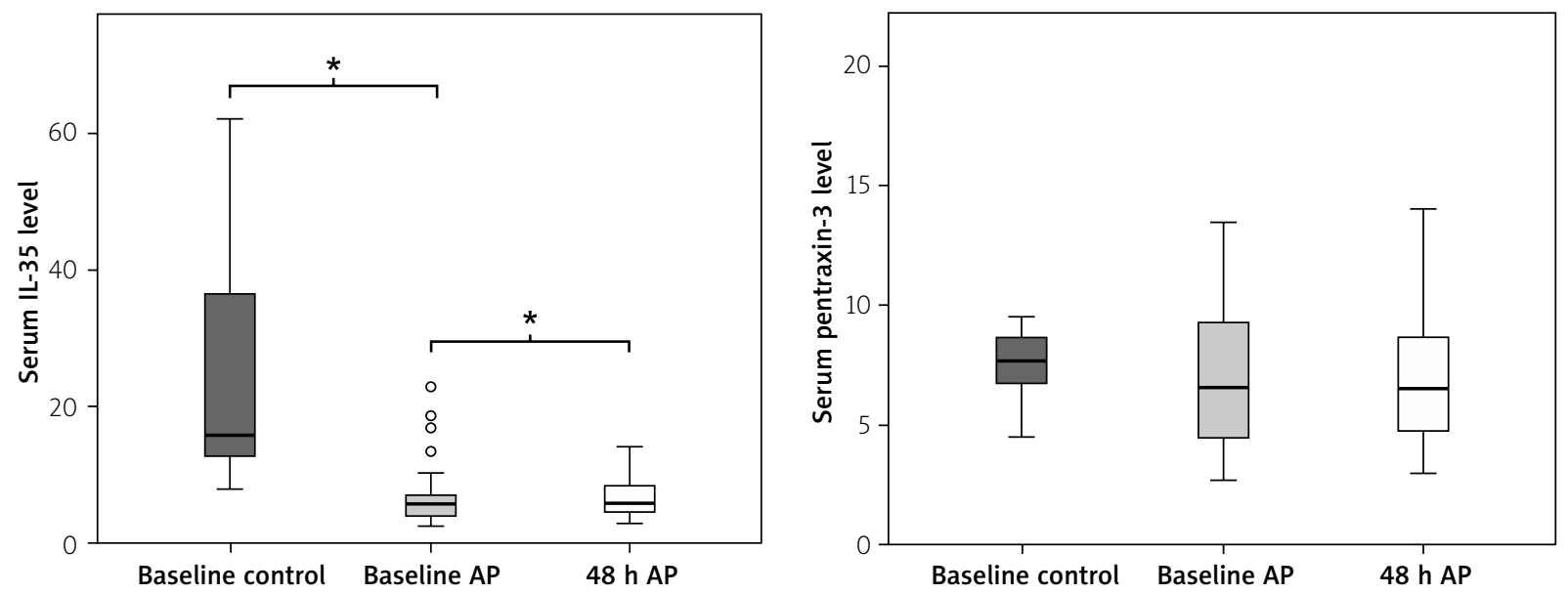

Figure 1. Serum IL-35 and pentraxin-3 levels of control group and AP patients at the time of diagnosis and at $48 \mathrm{~h}$

$(R=0.358, p=0.004$ and $R=0.272, p=0.018$, respectively). There was positive correlation between lipase and serum pentraxin- 3 levels at the $48^{\text {th }} \mathrm{h}(R=0.523$, $p<0.001)$. There was no correlation between serum IL-35 and pentraxin-3 levels at baseline and at $48 \mathrm{~h}$ and neutrophil and lymphocyte count (Table V).

\section{Discussion}

The roles of the anti-inflammatory cytokine IL-35 and acute-phase protein pentraxin- 3 have not yet been understood in AP patients. Our study demonstrates that, in patients with AP, serum IL-35 levels were lower than in the control group, and they represented a rising trend from baseline levels to 48-hour follow-up. We found no difference in terms of serum pentraxin-3 levels between patients and controls, nor between baseline and 48-hour levels.

It is known that atrophic acinar cells activate several inflammatory cells like macrophages and granulocytes, which release a number of pro-inflammatory cytokines such as IL-1, IL-6, IL-8, IL-18, IL-33, and TNF- $\alpha$ during pancreatic injury. There are several studies that shows higher levels of pro-inflammatory cytokines and the relation between systemic inflammatory response syndrome (SIRS) and multi-organ failure in $\operatorname{AP}[5,15,17]$. Anti-inflammatory cytokines including IL-10, IL-1 receptor antagonist, and soluble IL-2 receptor are also reported to be significantly higher in patients with severe acute pancreatitis $[18,19]$.

Table IV. IL-35, PTX-3, and CRP levels according to AP aetiology and radiological findings

\begin{tabular}{|c|c|c|c|c|c|c|}
\hline \multirow[t]{2}{*}{ Parameter } & \multicolumn{2}{|c|}{ IL-35 } & \multicolumn{2}{|c|}{ PTX-3 } & \multicolumn{2}{|c|}{ CRP } \\
\hline & $24 \mathrm{~h}$ & $48 \mathrm{~h}$ & $24 \mathrm{~h}$ & $48 \mathrm{~h}$ & $24 \mathrm{~h}$ & $48 \mathrm{~h}$ \\
\hline \multicolumn{7}{|l|}{ Aetiology: } \\
\hline Biliary & $6.30(4.66-8.11)$ & $6.87(5.10-9.53)$ & $6.34(4.26-8.92)$ & $6.85(4.70-8.86)$ & $2.50(0.81-5.72)$ & $2.87(0.85-11.48)$ \\
\hline Idiopathic & $5.60(3.63-6.81)$ & $5.98(4.13-9.32)$ & $7.16(4.54-10.97)$ & $6.41(4.85-9.91)$ & $1.60(0.65-4.39)$ & $1.07(0.49-5.58)$ \\
\hline$P$-value & $<0.05$ & $<0.05$ & $<0.05$ & $<0.05$ & $<0.05$ & 0.042 \\
\hline \multicolumn{7}{|l|}{ Ultrasonographic findings: } \\
\hline Pancreatic oedema & $7.23(4.87-17.57)$ & $8.80(6.16-12.93)$ & $5.71(4.22-8.86)$ & $5.42(4.06-8.92)$ & $2.80(1.01-10.22)$ & $2.35(0.97-9.85)$ \\
\hline $\begin{array}{l}\text { Pancreatic oedema and } \\
\text { peripancreatic fluid }\end{array}$ & $5.44(4.72-6.54)$ & $6.66(4.89-8.50)$ & $8.75(4.92-9.25)$ & $6.95(4.71-8.62)$ & $2.60(1.34-4.94)$ & $6.85(1.04-4.94)$ \\
\hline Normal findings & $5.66(3.40-6.87)$ & $5.64(4.21-8.91)$ & $6.80(4.42-10.63)$ & $6.75(4.88-9.06)$ & $1.26(0.58-3.76)$ & $1.23(0.30-6.97)$ \\
\hline$P$-value ${ }^{*}$ & $<0.05$ & $<0.05$ & $<0.05$ & $<0.05$ & $0.026^{\alpha}$ & $0.014^{\beta}$ \\
\hline
\end{tabular}

*Mann Whitney-U test was used for analysis. Alcohol and hypertriglyceridaemia groups were disregarded due to low sample size (2 patients in each group). Kruskal Wallis test was used for analysis. Peripancreatic fluid and pancreatic or peripancreatic necrosis groups were disregarded due to low sample size ( 2 patients in each group). ${ }^{\alpha}$ Between pancreatic oedema and normal findings; $p=0.037$. ${ }^{\beta}$ Between pancreatic oedema and peripancreatic fluid and normal findings; $p=0.042$. IL-35 - interleukin-35, PTX-3-pentraxin-3, CRP - C-reactive protein. 
Table V. Correlations between IL-35 and PTX-3 and selected biomarkers at 24 and $48 \mathrm{~h}$ from the onset of AP*

\begin{tabular}{|c|c|c|c|c|c|c|c|c|}
\hline \multirow[t]{3}{*}{ Parameter } & \multicolumn{4}{|c|}{ IL-35 } & \multicolumn{4}{|c|}{ PTX-3 } \\
\hline & \multicolumn{2}{|c|}{$24 \mathrm{~h}$} & \multicolumn{2}{|c|}{$48 \mathrm{~h}$} & \multicolumn{2}{|c|}{$24 \mathrm{~h}$} & \multicolumn{2}{|c|}{$48 \mathrm{~h}$} \\
\hline & $R$ & $P$-value & $R$ & $P$-value & $R$ & $P$-value & $R$ & $P$-value \\
\hline Amylase & 0.358 & 0.004 & 0.272 & 0.018 & 0.023 & $>0.05$ & 0.147 & $>0.05$ \\
\hline Lipase & 0.080 & $>0.05$ & -0.080 & $>0.05$ & 0.075 & $>0.05$ & 0.523 & $<0.001$ \\
\hline CRP & 0.239 & $>0.05$ & 0.047 & $>0.05$ & -0.109 & $>0.05$ & 0.166 & $>0.05$ \\
\hline SED rate & 0.116 & $>0.05$ & 0.352 & $>0.05$ & 0.215 & $>0.05$ & 0.197 & $>0.05$ \\
\hline $\mathrm{HDL}$ & 0.147 & $>0.05$ & 0.107 & $>0.05$ & -0.090 & $>0.05$ & 0.018 & $>0.05$ \\
\hline LDL & 0.194 & $>0.05$ & 0.135 & $>0.05$ & -0.275 & 0.044 & -0.126 & $>0.05$ \\
\hline Total Chol & 0.012 & $>0.05$ & -0.006 & $>0.05$ & -0.308 & 0.023 & -0.096 & $>0.05$ \\
\hline Calcium & -0.241 & $>0.05$ & -0.283 & $>0.05$ & 0.021 & $>0.05$ & -0.072 & $>0.05$ \\
\hline Glucose & 0.179 & $>0.05$ & 0.239 & $>0.05$ & -0.117 & $>0.05$ & -0.165 & $>0.05$ \\
\hline
\end{tabular}

${ }^{*}$ Pearson correlation was used for analysis. CRP - C-reactive protein, SED-sedimentation, HDL - high-density lipoprotein, $L D L-l o w$-density lipoprotein, Chol-cholesterol, IL-35 - interleukin-35, PTX-3-pentraxin-3.

IL-35 is a cytokine belonging to the IL-12 family, together with IL-12, IL-23, and IL-27. It consists of an IL-27p35 subunit and an Epstein-Barr virus-induced gene 3 subunit. IL-35 is an immunosuppressive cytokine mainly expressed by regulatory $T$ cells (Treg), dendritic cells, macrophages, and monocytes [20]. There are several studies that show higher IL-35 levels in patients with sepsis, arthritis, multiple sclerosis, diabetes, and atopic dermatitis [9, 21-24]. Also there are several studies that represent lower levels of IL-35 in patients with rheumatoid arthritis, Hashimoto's thyroiditis, and chronic immune thrombocytopaenia [13, 25, 26]. It is known that IL-35 exerts its immunosuppressive functions by promoting the differentiation of Treg and regulatory B (Breg) cells, inhibiting T-cell proliferation and T-helper 17 (Th17) differentiation, as well as manipulating the balance between Treg and Th17 [27, 28].

A study from China reported elevated serum IL-35 levels in patients with AP. In that study there were significant differences between severe and moderately severe AP and severe and mild AP patients. There was no significant difference between moderately severe and mild AP levels [29]. By contrast, in the present study serum IL-35 levels were lower in AP patients than in the control group. Although there was an increase in serum IL-35 level at $48 \mathrm{~h}$, this value was also lower than in the control group.

Acute-phase proteins, especially CRP, are commonly used in the diagnosis of acute pancreatitis and in the evaluation of prognosis. The highest CRP levels were shown at $48-72 \mathrm{~h}$ in various studies. Serum CRP levels higher than $12-15 \mathrm{mg} / \mathrm{dl}$ were correlated with severe pancreatitis [30]. Both CRP and pentraxin-3 belong to the pentraxin family; CRP is the representative form of 'short pentraxin' while pentraxin-3 is 'long pentraxin' [16].

Although there are studies that indicate correlation between higher pentraxin-3 levels in patients with AP, our study did not confirm this finding. We found no correlation between control group and patients with AP or with serum pentraxin-3 levels at baseline and at $48 \mathrm{~h}$. We found no difference in terms of serum CRP levels between baseline levels of AP patients and the control group, but there was a difference between baseline levels and serum CRP levels at $48 \mathrm{~h}(p=0.008)$. This is probably due to all our patients having mild pancreatitis. In a recently published study, the levels of pentraxin-3 were significantly higher in patients with severe acute pancreatitis than in patients with mild and moderately severe AP ( $p=0.014)$ [31]. Kusnierz-Cabala et al. also revealed higher serum pentraxin-3 levels in those with the severe compared to those with the mild form of AP (median 17.2 vs. $4.0 \mathrm{ng} / \mathrm{ml}$ on day $1, p=0.03$; 6.1 vs. 2.2 on day $5, p=0.044$ ) [32].

A major limitation of our study was the lack of a severe AP group, and the other is the medium sample size. To our knowledge, although this is the second study in which IL-35 was studied in patients with AP, it is the first one showing lower levels of IL-35 in patients with mild AP. At the 48-hour control an increase in baseline IL-35 levels was observed in mild AP patients. Again, although previous studies showed higher levels of pentraxin-3 in patients with AP, there was no difference in the pentraxin-3 level between the mild AP patients and the healthy control group in our study. 


\section{Conclusions}

Interleukin-35 may be used in the diagnosis and follow-up in patients with mild AP, but pentraxin-3 should not. Future clinical studies including large numbers of AP and severe AP patients are needed to clear the diagnostic and prognostic value of IL-35 and pentraxin-3 levels in AP patients.

\section{Conflict of interest}

The authors declare no conflict of interest.

\section{References}

1. Sarr MG, Banks PA, Bollen TL, et al. The new revised classification of acute pancreatitis 2012. Surg Clin North Am 2013, 93: 549-62.

2. Nesvaderani M, Eslick GD, Cox MR. Acute pancreatitis: update on management. Med J Aust 2015; 202: 420-3.

3. Tenner S, Baillie J, Dewitt J, et al. American College of Gastroenterology guideline: management of acute pancreatitis. Am J Gastroenterol 2013; 108: 1400-15.

4. Singh P, Garg PK. Pathophysiological mechanisms in acute pancreatitis: current understanding. Indian J Gastroenterol 2016; 35: 153-66.

5. Manohar M, Verma AK, Venkateshaiah SU, et al. Pathogenic mechanisms of pancreatitis. World J Gastrointest Pharmacol Ther 2017; 8: 10-25.

6. Chen CC, Wang SS, Lu RH, et al. Serum interleukin 10 and interleukin 11 in patients with acute pancreatitis. Gut 1999; 45: 895-9.

7. Pezzilli R, Billi P, Miniero R, et al. Serum interleukin-10 in human acute pancreatitis. Dig Dis Sci 1997; 42: 1469-72.

8. Devière J, Le Moine $\mathrm{O}$, Van Laethem JL, et al. Interleukin 10 reduces the incidence of pancreatitis after therapeutic endoscopic retrograde cholangiopancreatography. Gastroenterology 2001; 120: 498-505.

9. Cao J, Xu F, Lin S, et al. IL-35 is elevated in clinical and experimental sepsis and mediates inflammation. Clin Immunol 2015; 161: 89-95.

10. Tomcik M, Zerr P, Palumbo-Zerr K, et al. Interleukin-35 is upregulated in systemic sclerosis and its serum levels are associated with early disease. Rheumatology (Oxford) 2015; 54: 2273-82.

11. Chen C, Deng Y, Chen H, et al. Decreased concentration of IL-35 in plasma of patients with asthma and COPD. Asian Pac J Allergy Immunol 2014; 32: 211-7.

12. Li Y, Wang Y, Liu Y, et al. The possible role of the novel cytokines IL-35 and IL-37 in inflammatory bowel disease. Mediators Inflamm 2014; 2014: 136329.

13. Ning X, Jian Z, Wang W. Low serum levels of interleukin 35 in patients with rheumatoid arthritis. Tohoku J Exp Med 2015; 237: 77-82.

14. Sternby H, Hartman H, Johansen D, et al. IL-6 and CRP are superior in early differentiation between mild and non-mild acute pancreatitis. Pancreatology 2017; 17: 550-4.

15. Nieminen A, Maksimow M, Mentula P, et al. Circulating cytokines in predicting development of severe acute pancreatitis. Crit Care 2014; 18: R104.
16. Liu S, Qu X, Liu F, et al. Pentraxin 3 as a prognostic biomarker in patients with systemic inflammation or infection. Mediators Inflamm 2014; 2014: 421429.

17. Zhang XP, Li ZJ, Zhang J. Inflammatory mediators and microcirculatory disturbance in acute pancreatitis. Hepatobiliary Pancreat Dis Int 2009; 8: 351-7.

18. Mayer J, Rau B, Gansauge F, et al. Inflammatory mediators in human acute pancreatitis: clinical and pathophysiological implications. Gut 2000; 47: 546-52.

19. Makhija R, Kingsnorth AN. Cytokine storm in acute pancreatitis. J Hepatobiliary Pancreat Surg 2002; 9: 401-10.

20. Collison LW, Workman CJ, Kuo TT, et al. The inhibitory cytokine IL-35 contributes to regulatory T-cell function. Nature 2007; 450: $566-9$

21. Šenolt L, Šumová B, Jandová R, et al. interleukin 35 synovial fluid levels are associated with disease activity of rheumatoid arthritis. PLoS One 2015; 10: e0132674.

22. Akcali A, Zengin F, Aksoy SN, et al. Fatigue in multiple sclerosis: is it related to cytokines and hypothalamic-pituitary-adrenal axis? Mult Scler Relat Disord 2017; 15: 37-41.

23. Espes D, Singh K, Sandler S, et al. Increased interleukin-35 levels in patients with type 1 diabetes with remaining C-peptide. Diabetes Care 2017; 40: 1090-5.

24. Gürkan A, Yücel AA, Sönmez C, et al. Serum cytokine profiles in infants with atopic dermatitis. Acta Dermatovenerol Croat 2016; 24: 268-73.

25. Yilmaz H, Cakmak M, Ceydilek B, et al. Role of interlekin-35 as a biomarker in patients with newly diagnosed Hashimoto's thyroiditis. Endocr Regul 2016; 50: 55-61.

26. Yang Y, Xuan M, Zhang X, et al. Decreased IL-35 levels in patients with immune thrombocytopenia. Hum Immunol 2014; 75: 909-13.

27. Collison LW, Chaturvedi V, Henderson AL, et al. IL-35-mediated induction of a potent regulatory $T$ cell population. Nat Immunol 2010; 11: 1093-101.

28. Shen P, Roch T, Lampropoulou V, et al. IL-35-producing B cells are critical regulators of immunity during autoimmune and infectious diseases. Nature 2014; 507: 366-70.

29. Zhang YL, Zhou XY, Guo XY, et al. Association between serum interleukin-35 levels and severity of acute pancreatitis. Int J Clin Exp Med 2015; 8: 7430-4.

30. Rettally CA, Skarda S, Garza MA, et al. The usefulness of laboratory tests in the early assessment of severity of acute pancreatitis. Crit Rev Clin Lab Sci 2003; 40: 117-49.

31. Deng LH, Hu C, Cai WH, et al. Plasma cytokines can help to identify the development of severe acute pancreatitis on admission. Medicine (Baltimore) 2017; 96: e7312.

32. Kusnierz-Cabala B, Gurda-Duda A, Dumnicka P, et al. Plasma pentraxin 3 concentrations in patients with acute pancreatitis. Clin Lab 2013; 59: 1003-8.

Received: 2.08 .2018

Accepted: 11.10 .2018 